\title{
Examining Scientific Attitude Scales in India: Development and Validation of a New Scale
}

\author{
Moheeta Khan ${ }^{1^{\star}}$, Mohd Abid Siddiqui ${ }^{1}$
}

${ }^{1}$ Aligarh Muslim University, INDIA
${ }^{*}$ Corresponding Author: moheetakhan@gmail.com

Citation: Khan, M., \& Siddiqui, M. A. (2020). Examining scientific attitude scales in India: Development and validation of a new scale. Interdisciplinary Journal of Environmental and Science Education, 16(4), e2223. https://doi.org/ 10.29333/ijese/8557

\begin{tabular}{|c|c|}
\hline RTICLE INFO & ABSTRACT \\
\hline $\begin{array}{l}\text { Received: } \\
1 \text { April } 2020\end{array}$ & $\begin{array}{l}\text { In India a multitude of scientific attitude scales are available through various channels. The scales are } \\
\text { standardized under local settings and most of the Indian researchers utilize these national level scales } \\
\text { for the assessment of scientific attitudes. In this work } 23 \text { such Indian scales are reviewed over their }\end{array}$ \\
\hline Accepted: & psychometric properties. The study showed that most of the scales lack theoretical foundations and \\
\hline 28 July 2020 & psychometric evidences. A scale by Bajwa \& Mahajan (2012) is selected over its appropriate theoretical \\
\hline & $\begin{array}{l}\text { background. But many of the items are inappropriate, they failed in the validity check-up through } 11 \text {-ex- } \\
\text { perts and } 218 \text {-student tryout. Thus, a new scale is developed by retaining some of the items of the scale. }\end{array}$ \\
\hline & $\begin{array}{l}\text { The developed scale is standardized and validated through } 200,312 \text { and } 641 \text { student tryouts. All state- } \\
\text { ments in the developed scale show high item to scale correlation values. Exploratory factor analysis (EFA) }\end{array}$ \\
\hline & $\begin{array}{l}\text { confirms the five sub-scales namely rationality, curiosity, open-mindedness, aversion to superstition and } \\
\text { confidence in scientific method. The Cronbach's alpha coefficient value of the scale is high i.e. 0.79. The }\end{array}$ \\
\hline & $\begin{array}{l}\text { scale establishes its content, construct, concurrent and discriminant validities. This study results in to a } \\
\text { valid scientific attitude scale that can be utilized in further researches. }\end{array}$ \\
\hline
\end{tabular}

Keywords: scientific attitude, scale development, factor analysis

\section{INTRODUCTION}

Affective domain variables are recognized as important factors in science education (Fraser, 1978; Gauld \& Hukins, 1980; Osborne, Simon, \& Collins, 2003; Schibeci, 1981). These variables largely concern the student attitudes related to science (Gardner, 1975; Schibeci, 1984). Over several decades the two important aspects of attitudes such as 'attitude towards science' and 'scientific attitudes' have been studied by the science education researchers. Numerous researchers have investigated the 'attitudes towards science' in context to science education (Koballa \& Glynn, 2013). While, the 'scientific attitudes' were more popular in earlier science education researches. Researchers have debated over the definition (Aiken \& Aiken, 1969; Baumel \& Berger, 1965; Billeh \& Zakhariades, 1975; Gauld \& Hukins, 1980; Jones \& Butts, 1983; Lawson, 1959; Noll, 1935), development (Aiken \& Aiken, 1969; Drake, 1935; Haney, 1964; Heiss, 1958; Jones \& Butts, 1983; Kozlow \& Nay, 1976) and impact in schools (Aiken
\& Aiken, 1969; Drake, 1935; Heiss, 1958; Jones \& Butts, 1983; Khan, 1962; Kozlow \& Nay, 1976). But all across the world, there are meager researches over scientific attitudes now-a-days (Ekawati, 2017; Mahulae, Sirait, \& Sirait, 2017). However, scientific attitudes in context to science education are quite more popular among researchers in India. One of the reasons might be the importance of scientific attitudes among the curriculum designers in India. All the educational documents emphasize on the development of various scientific attitudes as primary aims of science teaching in India (National Curriculum Framework, 2005; Government of India, 1986; National Council of Educational Research and Training, 2006). The secondary school curriculum highlights the requirement of scientific attitudes among the students. Yet on practical basis, the central government autonomous education body, Central board of Secondary Education (CBSE) has only included it among 'general studies' in schools (CBSE, 2019). Unfortunately, the schools do not have any fixed 
guidelines for the development and assessment of scientific temperament/scientific attitudes. Their assessment is being done internally by the schools with no weightage is student overall academic performances (CBSE, 2016). As a result, many schools do not even recognize the importance to these attitudes in classroom practices. Further, the state authorities who have separate schools than CBSE do not even mention them in their curriculum.

Thus, realizing the importance and lack of proper dissemination of scientific attitudes in schools, science education/education researchers in India have always studied different aspects of scientific attitudes. Over a span of time an extensive literature is available concerning the scientific attitudes among Indian students. The studies have focused over the development of scientific attitudes (Balaji, 2017; Candrasekaran, 2014; Smitha, 2012; Sumita, 2017). Researchers have identified the impact of scientific attitudes over the student science achievement (Ahmed, 2007; Ahuja, 2017; Kaur, Niwas, \& Rai, 2015; Khan \& Siddiqui, 2018; Lucas, 2016; Rashmi \& Betsur, 2017; Ravi, 2013; Shanthi, 2014; Srivastava, 2014). Various other variables have also been studied with it, such as science interest, cognitive styles, self-efficacy, reasoning, aptitudes etc. (Barot, 2013; Baweja, 2017; Ghosh, 1986; Kavitha \& Venkateswaran, 2014; Rao, 2003, 2004; Singh, 1993; Singh \& Bai, 2017; Srivastava, 2013; Trivedi \& Agarwal, 2016). Some researchers have also explored gender differences in scientific attitudes (Barot, 2013; Gupta, 2015).

There are several available instruments for the measurement of scientific attitudes, they have been universally utilized (Billeh \& Zakhariades, 1975; Jones \& Butts, 1983; Moore \& Foy, 1997; Noll, 1935; Supardi, Istiyono, \& Setialaksana, 2019). But, almost every study in India utilize the nationally standardized scales. There exist more than ten published scientific attitude scales in India. Moreover, many researchers reported the development of their own instruments or adaption of an already existing scales. Altogether there exist more than 30 instruments that are standardized over the Indian population. Each scale differs in theoretical backgrounds, sub-scales, populations, validity-analyses etc. Many of these scales are single study usage. One may get confused over the large number of available scales and their psychometric evidences. Since, if a scale is not validated efficiently or it lacks good theoretical foundation, it cannot measure what it claims to measure (Blalock et al., 2008). If researchers utilize faulty data instruments the results will have no meanings.

This study addresses two research questions 1 ) Is there any valid scientific attitude scale in India, and 2) What is the validity of the newly developed scientific-attitude scale. The present study is thus based on the identification and evaluation of the available scientific attitude scales in India. After a review of total 23 such scales, the Bajwa \& Mahajan (2012) scale was selected over its theoretical foundation, but it too failed in its psychometric evidences. The study thus aimed at the development of a new scale which would be standardized over a large population and that can be utilized by further researchers. The development procedure involved retention of some of the items from Bajwa \& Mahajan (2012) scale, with modification, deletion and addition of many other items. The standardization and validation of the newly developed scale are expressed in detail in this paper.

\section{Review of Scientific Attitude Scales}

Currently, different types of scales are in use in India. First, the standardized and published scales that are made available through various agencies. These agencies publish and provide standardized scales for the larger populations. Some of the popular agencies are the National Council of Educational Research \& Training (NCERT), New Delhi and National Psychological Corporation (NPC), Agra. Second, there are some other scales published in educational journals, they are developed by the researchers for their specific-research purposes. Third, there are unpublished scales that are either adapted from a standardized scale or are small study scales. The standardized and published scales are quite popular among the researchers, since one can directly buy and utilize them. Figure 1 explains the different types of scales available in India. We searched for all available scientific attitude scales in India. The National Library of Educational \& Psychological Test by NCERT does not show to have any scientific attitude scale in its 2019 catalogue (National Council of Educational Research and Training, 2019). The NPC 2019 catalogue have some popular scientific attitude scales developed by Kaur \& Gakhar, Grewal, Bajwa \& Mahajan, Bhagwat, and by Kaur \& Rani (National Psychological Corporation, 2019). It is to be noted that the publication year of these scales are different. Since these scales are repeatedly available in different earlier NPC catalogues as well.

\section{Standardized Scales}

The NPC scales differ in their sample, statements and techniques of standardizations. They have different definitions of scientific attitude in terms of different subscale dimensions. The scale by Gakhar \& Kaur (1985) scale has 61 items in 9 dimensions of scientific attitude namely curiosity, open-mindedness, faith in scientific method, cause \& effect relationship, critical mindedness, seeks evidence, objectivity, suspended judgement, and aversion to superstition. The test has established the test-retest reliability and its content validity through expert opinions. 


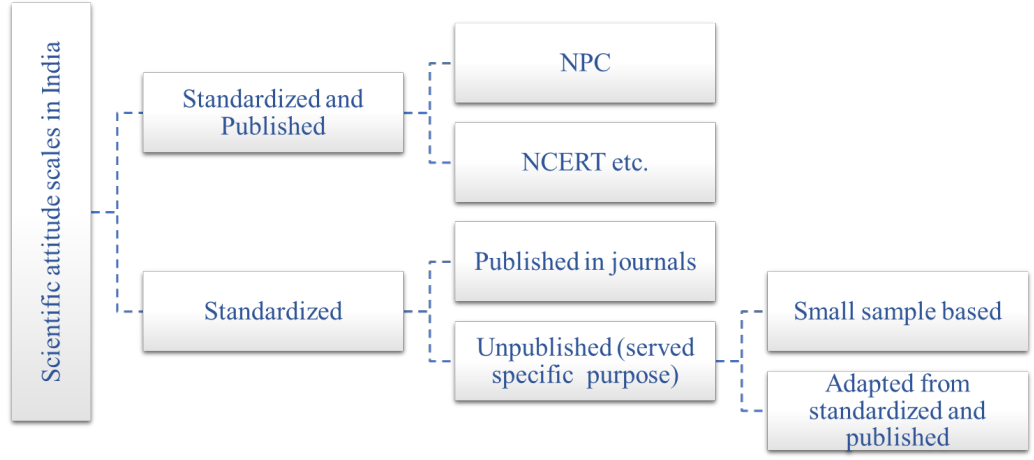

Figure 1. Different forms of scientific attitude scales available in India

Grewal (1990) developed science attitude scale of 20 items among positive intellectual, negative intellectual, positive emotional, and negative emotional dimensions. Bajwa \& Mahajan (2012) has 49 items among rationality, curiosity, open-mindedness, aversion to superstition, and faith in scientific method sub-scales. Bhagwat (2006) has 20 items for a larger age group of $17-55$ years. The scale by Kaur \& Rani in NPC is quite unpopular, to our knowledge no research was found to utilize it.

Apart from these agencies, some other scales are also available, they are quite popular among the researchers. For example, the scientific attitude questionnaire developed by Misra (2008). It has 112 statements in two components intent and action, the reliability of the scale was established through test-retest and split-half methods. A scale standardized by utilizing a detailed standardization procedure of factor analysis was also developed (Dani, 1989). Sagar (2003) has also developed a scientific attitude scale for higher education, it includes the sub-scales of rationality, curiosity, open-mindedness, aversion to superstitions, objectivity of intellectual belief, suspended judgement and theory building. The scale by Sood \& Sandhya (1978) is also standardized and it is employed by a number of researchers (Hunashal, 2013).

\section{Locally Standardized Scales}

Some researchers have developed local scales for their specific research purposes. For example, a rating scale for scientific attitude was developed (Ramya, 2018). Scientific attitude scale by Rasani consists of 30 statements, standardized over 50 students (Rasani, 2017). A scale was developed and standardized over 150 students in Assamese, English and Bengali languages (Sudipta, 2015). A local scale was developed for a specific grade 10 (Bhattacharjee, 2015). Ahmed developed a small scale involving rationality, curiosity, open-mindedness, aversion to superstitions, personal confidence, suspended judgement, and objectivity of intellectual beliefs sub-scales (Ahmed, 2007). Another researcher developed a local scale in Bengali language (Ghosh, 1986). Jain (1967) also developed a scale of 30 statements in intellectual, affective, cognitive and metaphysical-mythological domains. The scale had been standardized over 50 students, the reliability coefficient is 0.63 .

There are several researchers who developed some local scales for their doctoral researches (Ravi, 2013; Singh, 1993; Sumita, 2017). One researcher have developed a scale for the assessment of the scientific attitudes of the parents (Ramachandra, 2017). Srivastava (1980) developed a scientific attitude scale in Hindi. There are some other researchers who have standardized scales by adapting the statements of an already existing scale of scientific attitudes. For example, researchers have adapted the already standardized scale by Sood \& Sandhya (Ranganath, 2012; Rao, 2003). The adaptations simply involved addition of some extra items or subtraction of some of the items. Adaptation is also done to translate a standardized scale into the regional languages (Rao, 2004).

\section{Difficulties in Available Scientific Attitude Scales in India}

Each of the available scientific attitude scales in India has different contexts, sub-scales, standardizations etc. To select one appropriate scale, all the available scales were reviewed. However, the review should be on some basis of quantitative evaluation so that all the scales can be judged over similar parameters. The scales were evaluated over the following parameters;

1. The size of study population

2. Genders, language (Hindi, English or others) and grade level of the study population

3. Theoretical background

4. Reliability and validity calculations

5. Usability (no. of items/ sub-scales and fitting of the statements in scale)

One of the major drawbacks encountered among most of the scientific attitude scales in India is lack of strong 
theorization or standardization procedures. Different researchers defined scientific attitudes in various ways. Each scale possesses a set of sub-scales, some are common, and some are different without any evidence of chosen sub-variables. Though the possession of different sub-scales is not a problem, since long the researchers report differences and overlapping in components of scientific attitudes (Billeh \& Zakhariades, 1975; Haney, 1964; Heiss, 1958; Kozlow \& Nay, 1976). But, each scale possesses some serious technical defects that cannot be ignored. For example, Gakhar \& Kaur (1985) scale is quite old and it has 61 items. The scale statements are quite outdated, unclear and unfitting in their presentation. The reliability is established through test-retest over just 30 students, which is very small. While the validity is established through fout expert opinion only. The scale seems to fail in validity and usability parameters.

The Grewal (1990) scale of scientific attitude is standardized and published scale, yet it confuses among the concept of scientific attitude and attitude towards science. The scale claims to measure scientific attitudes but all its dimensions and statements consider the attitude towards science domains. For example, it has statements like 'science subject is more entertaining than other subjects' or 'it is boring to study science'. The scale discarded the initial draft statements based on their t-values. The scale is poorly standardized. Bhagwat (2006) standardizes a scale for the 17-55 years age group, since our focus is on a scientific attitude scale for the academic purpose only. The scale loses its importance over the school students, the items are quite general that do not fit into the student academic-assessments. The scale by Misra (2008) has 112 statements, that require around 2 hours for completion. One cannot logically think of assessing such long scales over the students in the school premises. One of the scale was developed through good standardization procedures, but unfortunately the scale is not published and its statements are not available in general for the researchers (Dani, 1989). Sood \& Snadhya (1978) scale is very old, the same is visible from its statements. For example, its first statement says, 'Now it is not possible to develop more sensitive $x$-ray machine', it might have considered $x$-rays as an achievement of science but now we are much ahead in terms of scientific innovations.

Apart from the drawbacks in the published and standardized scales, the locally standardized scales also have some serious issues. One such scale has confusion among the notion of scientific attitudes and attitudes towards science (Rasani, 2017). A scale has weak standardization (Ramya, 2018). Another scale have unclear sub-scales (Bhattacharjee, 2015). One scale did not explain the procedure of reliability and validity calculations (Ahmed,
2007). Some other scale lack the explanation of the extent of change in the original scale in adaptation (Ranganath, 2012). Mostly, the locally standardized scales are poorly standardized since their purpose was to fulfill a single research purpose only. The languages of some of the statements in the scales is also uncomprehending. It can be concluded that almost every scale has some technical, standardization or language related issues.

\section{METHOD}

The research methodology involved selection of an appropriate scale from the available scientific attitude scales in India, checking its validity, modifying it and at last establishing the validity of a new scale for the assessment of scientific attitudes among the students. Since most of the scales has serious technical issues as described in the review section, they could not be utilized while aiming for good research results. However, among all the available scales, the scale by Bajwa \& Mahajan (2012) can be considered on the basis of its background foundations. The scale is standardized and published through NPC (National Psychological Corporation, 2019). Though the scale has poor standardization over 52 students, it claims a reliability coefficient of 0.97 . The content-concurrent validities of the scale are also established through 10 field experts. The standardization over just 52 students utilizing t-value calculations is inadequate for the scale generalization over large population. The standardization procedures could be made better over a large sample by involving more quantitative techniques like exploratory factor analysis.

The Bajwa \& Mahajan (2012) scale has good description of the sub-scales involved in it. The scale itself failed to justify the selection of its five sub-scales, but the subscales are in line with the categories of scientific attitudes as defined by Gauld \& Hukins (1980). Review article by Gauld and Hukins explains that scientific attitude has a scientific and an affective dimension. The scientific dimension has a set of different components under three categories. These categories include ' 1 ) general attitude towards ideas and information (2) attitudes related to the evaluation of ideas and information, and (3) commitment to scientific beliefs' (Gauld \& Hukins, 1980). The components of scientific attitudes that fall under these three categories are also explained by Gauld \& Hukins (1980). While, the sub-scales of the Bajwa \& Mahajan (2012) scale have similar categories that lie among the three given categories. 'Curiosity' and 'open-mindedness' fall under first category, 'rationality' represents the second, the 'faith in scientific methods' and 'aversion to superstitions' subscales represent the third category. Thus, the sub-scales of the scale are based on the description of scientific 


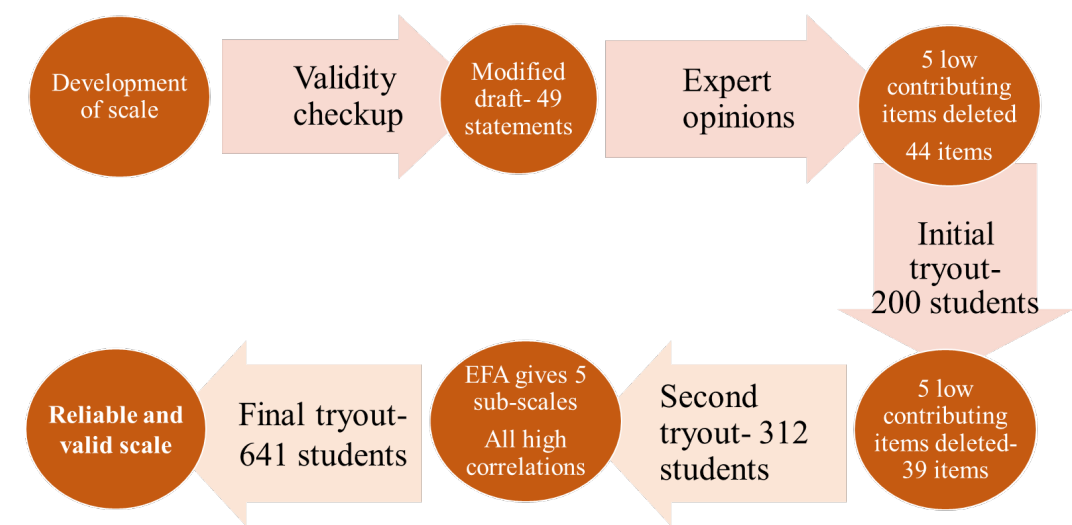

Figure 2. Development procedure of the new scientific attitude scale

attitudes by Gauld \& Hukins (1980). A stepwise procedure was carried out for the development of a new scale of scientific attitudes. Figure 2 represents the procedure in detail.

\section{Reliability and Validity Checkup}

The uncertainties among the individual items of the Bajwa \& Mahajan (2012) scientific attitude scale were checked up in two steps. Firstly, 12 professors of science education in India were contacted and their opinions about the individual items were considered. The experts doubted the appropriateness of 8 scale items, which sheds the content validity of the scale. For example, the sub-scale 'aversion to superstition' has been identified to have many inappropriate statements. It has statements like 'there is life after death', 'heaven and hell exist', or 'stories of rebirth are true'. Though these statements are in contradiction of having scientific attitudes, but they somehow contradict the religious beliefs of the students. Since India as a country has rich traditional and religious values, but to carry religious values is different from carrying superstitious values. It might be a different debate, but to avoid ambiguities the scale could have covered other aspects of superstitions. One of the statements in the rationality dimension is 'science can be studied by male only'. This statement was discarded by all the experts, it shows gendered opinion which is hard to answer over a five-point scale. Such ambiguous statements of a scale may give misleading results.

Secondly, to carry out a quantitative checkup, a tryout of the scale was conducted over 218 students. It involved grade 11 and grade 12 students from 4 schools of western Uttar Pradesh state in India. The student scores were in line with the expert opinions, as it showed that the Cronbach's alpha coefficient value of the scale was quite low i.e. 0.56, which was further smaller for the aversion to superstition sub-scale i.e. 0.41. Such smaller alpha values are inappropriate and questionable (George \& Mallery,
2003). The item number $2,16,17,24,29,39,40,41,42,43$, $44,45,46$ and, 47 in the scale were found to have very low or even negative correlations with the scale (see Table 1 ).

These results show that many statements in the scale are statistically inappropriate. The scale failed to be generalized over the current population of India. It drifted towards the rejection of the scientific attitude scale by Bajwa \& Mahajan (2012) as well. None of the scale was found to be suitable for the assessment of scientific attitudes among the students. The need of a new scale can be easily felt. However, the scale by Bajwa \& Mahajan (2012) holds strong theorization, though some of the scale statements are poorly correlated with the scale. It suggests for the modification of the current scientific attitude scale as a good attempt to have a reliable and valid scientific attitude scale. Adaptation may be done in terms of removing/ modifying the low and negatively correlated items, as well as addition of some new items. The development and validation procedure of the new scale is discussed in the next section.

\section{FINDINGS AND RESULTS}

The very first step towards the development of a new scale was to prepare a modified draft of the Bajwa \& Mahajan scale. The development involved the modifications in the language of the statements. Firstly, the statement pointed out by the experts in previous steps i.e. 'science can be studied by male only.' was replaced by new statement 'Science is suitable for all students regardless of the gender'. Secondly, many other statements were reframed such as 'science and religion cannot go together' was replaced by 'science has better explanation of things than religion' etc. The development of the scale also involved complete removal of 10 statements from the scale and 10 new statements were added. The modified draft contained 49 statements in 5 sub-scales of the scale, which can be subjected for further analysis. Since 
Table 1. Item-scale correlations from Bajwa \& Mahajan (2012) scientific attitude scale

\begin{tabular}{|c|c|c|c|c|c|c|c|}
\hline 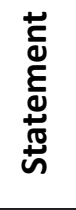 & $\begin{array}{l}\text { Item-scale } \\
\text { corr.* }\end{array}$ & 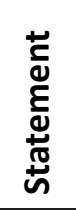 & $\begin{array}{l}\text { Item-scale } \\
\text { corr.* }\end{array}$ & 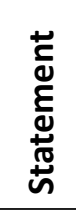 & $\begin{array}{l}\text { Item-scale } \\
\text { corr.* }\end{array}$ & 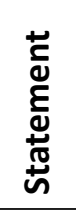 & $\begin{array}{l}\text { Item-scale } \\
\text { corr.* }\end{array}$ \\
\hline 1. & 0.16 & 14. & 0.45 & 27. & 0.35 & 40. & 0.14 \\
\hline 2. & -0.05 & 15. & 0.61 & 28. & 0.35 & 41. & -0.23 \\
\hline 3. & 0.41 & 16. & -0.03 & 29. & 0.12 & 42. & 0.08 \\
\hline 4. & 0.38 & 17. & -0.11 & 30. & 0.31 & 43. & -0.14 \\
\hline 5. & 0.36 & 18. & 0.47 & 31. & 0.60 & 44. & 0.18 \\
\hline 6. & 0.29 & 19. & 0.34 & 32. & 0.35 & 45. & 0.10 \\
\hline 7. & 0.54 & 20. & 0.39 & 33. & 0.57 & 46. & 0.02 \\
\hline 8. & 0.31 & 21. & 0.41 & 34. & 0.55 & 47. & -0.01 \\
\hline 9. & 0.34 & 22. & 0.42 & 35. & 0.41 & 48. & 0.34 \\
\hline 10. & 0.39 & 23. & 0.56 & 36. & 0.32 & 49. & 0.42 \\
\hline 11. & 0.37 & 24. & -0.02 & 37. & 0.43 & --- & --- \\
\hline 12. & 0.46 & 25. & 0.38 & 38. & 0.55 & --- & --- \\
\hline 13. & 0.34 & 26. & 0.43 & 39. & 0.17 & --- & --- \\
\hline
\end{tabular}

*corr. is the abbreviation used for correlation.

the draft scale is a Likert type five-point scale, it has both positive and negative polarity statements. The students get 5 to 0 scores from strongly agree to strongly disagree for a positive polarity statement, while opposite scores in the negative polarity statements (score 0 for strongly agree to 5 for strongly disagree). There are 15 negative polarity statements that are identified with an asterisk in the final version of the scale (see Table 2).

\section{Content validity of the draft scale}

The modified draft was subjected to expert's opinions from 11 science educators across India. The experts were contacted to establish the face and content validities of the scale, and to gain an insight in to any technical deformities in the scale statements. The experts were requested to provide their opinions regarding the appropriateness of each of the statement as a measure of scientific attitudes. The expert opinions were utilized to calculate the content validity ratios (CVR) as described by Lawshe (1975) formula.

$$
C V R=\frac{n_{e}-N / 2}{N / 2}
$$

Here, $\mathrm{N}$ represents the total number of experts and $\mathrm{n}_{\mathrm{e}}$ represents the number of experts who marked a statement as essential. The CVR values for all the statements were calculated and 5 statements having smaller CVR values $(<0.56)$ were discarded, since they were not significant (Lawshe, 1975). It resulted in to another modified draft of the scale with 44 statements. The 44 -statement scale was conducted over 200 students. The sample included grade 11 and grade 12 students among 5 senior secondary schools in India. The item-scale correlations were calculated for all the items, five statements had lower correlational values with scale total $(<0.25)$ were deleted (Nunnaly, 1978). Thus, the new modified draft had 39 normalized items, they were approved by the experts, and standardized over 200 students. These 39 statements can be subjected to a larger population for quantitative evaluations. Before this, the scale was subjected to a class of 28 students for the language test. The students were asked to mention any difficulties in each statement of the scale. They felt no difficulties in comprehending any of the statement, thus the scale was considered to have unambiguous language. Finally, the modified scale was subjected to a larger population of 312 and 641 students for the final analyses.

\section{Exploratory Factor Analysis (EFA)}

The modified draft of scientific attitudes with 39-statements was subjected for exploratory factor analysis (EFA) and item-scale correlations were calculated. The draftscale was carried out over 312students, it included grade 12 students in 8 schools in Uttar Pradesh state in India. The data included 186 male and 126 female students. The EFA show that the KMO measure and Bartlett's test 
Table 2. Factor structures and factor loadings in the developed scientific attitude scale

\begin{tabular}{|c|c|c|c|c|c|c|}
\hline \multirow{2}{*}{$\underset{\dot{n}}{\dot{0}}$} & \multirow{2}{*}{ Items } & \multicolumn{5}{|c|}{ Factor loadings } \\
\hline & & $\mathbf{F 1}$ & F2 & F3 & F4 & F5 \\
\hline
\end{tabular}

\section{Rationality}

1. Traditional society hampers the growth of science.

0.75

2. Science is suitable for all students regardless of the gender.

0.75

3. Scientific careers are more useful to the advancements in the society.

0.74

4. Studying science is not everybody's cup of tea.

$5^{\star}$. Traditional beliefs should be accepted even when they are against scientific research.

6. Studying science subjects enhance our intellect.

$7^{\star}$. Scientist does not live normal family life.

\section{Open-mindedness}

$8^{\star}$. Science makes us dependent on machines.

9*. Sharing knowledge with others is harmful.

10. Any new thing can be criticized in the absence of facts.

11. Science subjects have infinite opportunities.

$12^{\star}$. Science is responsible for low moral standards.

13. Positive criticism is useful for advancement of knowledge.

$14^{\star}$. Opinion of novice (new / un-experienced person) should be rejected even though supported by evidence.

$15^{\star}$. Scientific advancements have only adverse effects on mankind.

16. Study of science helps in thinking new ideas.

$17^{\star}$. One may feel offended from a person who has different thinking from him/her.

\section{Confidence in Scientific Method}

18. Enough evidences should be collected before accepting an idea.

19. Testing of knowledge should be procedural.

20. One should be honest and truthful in collecting and recording data.

$21^{\star}$. Data can be manipulated according to the need.

22. One should suspend (delay) his/her decision in the absence of sufficient data.

23. Known is the basis to know the unknown.

24. Questioning attitude helps in defining a problem.

25. Any hypothesis should be accepted or rejected on the basis of sufficient evidence.

26. Knowledge should be considered tentative.

\section{Curiosity}

27. One should explore the unknown.

28. There is no conclusion as final or ultimate. 
Tablo 2. Contiuned

\section{$\sum_{i}^{\circ} \quad$ Items}

Factor loadings

$\begin{array}{lllll}\text { F1 } & \text { F2 } & \text { F3 } & \text { F4 } & \text { F5 }\end{array}$

29. There is a scientific cause for everything that takes place in this world.

0.78

$30^{\star}$. To do enquiry is a task of scientists and not of common man.

0.73

31. One should be interested to know 'WHY' of natural phenomenon.

0.69

32. One should search for reality behind appearances.

0.64

\section{Aversion to Superstition}

33. Scientist should report his/her discovery even if it is contradictory to religion. 0.68

$34^{\star}$. Use of lemon and green chilies protects from evil eye. 0.64

35*. Ghosts exist. 0.62

$36^{\star}$. For the solution of a problem one should go to an astrologer. 0.56

37. There is nothing like fate man makes his own fate. 0.52

38*. Praying/recitation of mantras before exam helps to score more marks. 0.48

39*. A black cat when crosses one's path, brings bad luck. 0.45

of sphericity had significant value of $0.941(p<0.01)$. It explains that the data is suitable for the EFA and further analysis can be carried out (Costello \& Osborne, 2005). It also represented that the multivariate variables in the scales are correlated with each other. The communalities values were also found to be high for all the statements, since they range from 0.491 to 0.717 (Velicer \& Fava, 1998; Field, 2009). The rotational component matrix explained the presence of five factors/sub-scales in the draft scale. It was also confirmed through the scree plot of the scale (see Figure 3) (Cattell, 1966). The total variance explained by the statements was found to be $59.7 \%$. It signified that the five sub-scales of the draft-scale were explaining $59.7 \%$ of the scientific attitude variable, which is quite high. The factor loadings of all the statements were also high (>0.4). It indicated that all the statements are appropriate, they can be retained in the scale (Costello \& Osborne, 2005). The factor structures and factor loadings of all the statements can be seen in Table 2 .

\section{Correlation Analysis}

The next step was to confirm the correlation of each of the statement to the scale total. Since the low correlated items were already deleted. This analysis would further

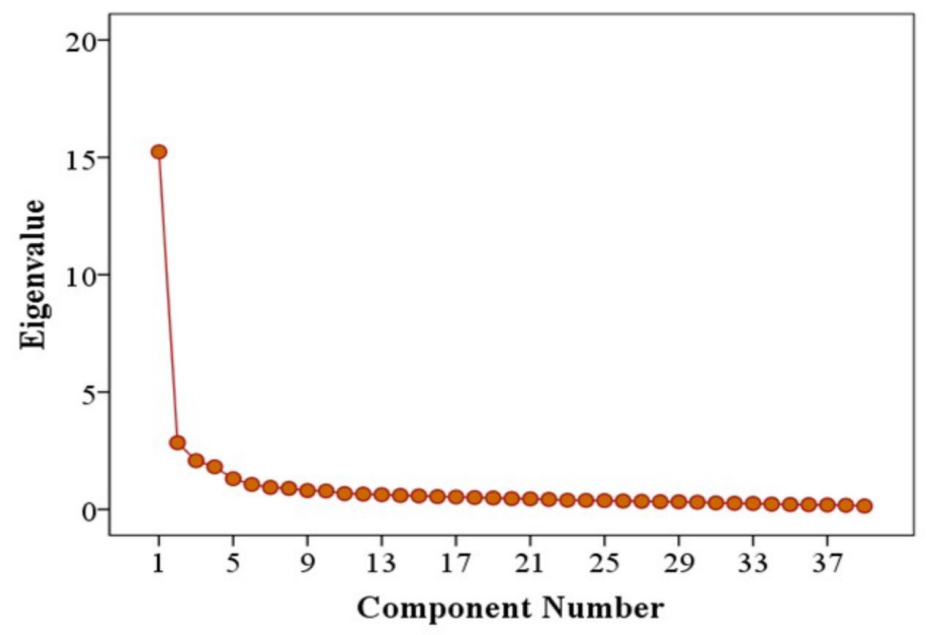

Figure 3. Scree plot of the scientific attitude scale draft 
confirm the stability of the draft scale. Table 3 explains the correlational coefficient values between each item and the scale that were calculated over 312 students. It also represents the correlation between each sub-scale and the scale total sores.

The item-scale correlation coefficient values over the 312-student data were all positive and high. The values are sufficient, and they represent the appropriateness of all the statements in measuring the scientific attitude variables (Nunnaly, 1978; Cohen, 1988). These coefficients were quantitative conformation for the content validity of the scale, which was established from the expert-opinions as well. Table 3 also determined the subscale-toscale correlation coefficients, it established the construct validity of the scale as well. To carry out an extensive reliability and validity test of the scale a final tryout of the draft-scale was performed.

\section{Reliability and Validity Analyses}

To estimate the reliability coefficient of the scientific attitude scale Cronbach's alpha value was calculated over another 641 grade 12 students in Uttar Pradesh State in India. The scale showed high reliability coefficient of 0.79 . It represented that the newly developed scientific attitude scale is reliable to be utilized for further researches (Nunnaly, 1978; De Vellis, 2003; Field, 2009). The separate reliability coefficients for each of the male and female samples were also calculated. The results show that the male and female samples have 0.73 and 0.83 respective values of Cronbach's alpha coefficients. These values represent similar and high alpha values for both the genders

Table 3. Correlation coefficients for all the statements and sub-scales of draft scale

\begin{tabular}{|c|c|c|c|c|c|c|c|}
\hline Item No. & 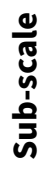 & $\begin{array}{l}\text { Item-scale } \\
\text { corr.* }\end{array}$ & $\begin{array}{l}\text { Sub- } \\
\text { scale-scale } \\
\text { corr. }^{\star}\end{array}$ & $\stackrel{\mathscr{E}}{ \pm}$ & 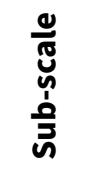 & $\begin{array}{l}\text { Item-scale } \\
\text { corr. }\end{array}$ & $\begin{array}{l}\text { Sub- } \\
\text { scale-scale } \\
\text { corr.* }^{*}\end{array}$ \\
\hline 1. & \multirow{7}{*}{ 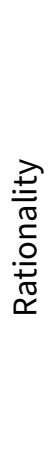 } & 0.37 & \multirow{7}{*}{0.58} & 21. & \multirow{6}{*}{ 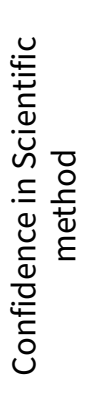 } & 0.48 & \multirow{6}{*}{0.79} \\
\hline 2. & & 0.54 & & 22. & & 0.51 & \\
\hline 3. & & 0.62 & & 23. & & 0.62 & \\
\hline 4. & & 0.38 & & 24. & & 0.71 & \\
\hline 5. & & 0.39 & & 25. & & 0.34 & \\
\hline 6. & & 0.41 & & 26. & & 0.56 & \\
\hline 7. & & 0.52 & & 27. & \multirow{6}{*}{$\frac{?}{\frac{7}{n}}$} & 0.61 & \multirow{6}{*}{0.77} \\
\hline 8. & \multirow{10}{*}{ 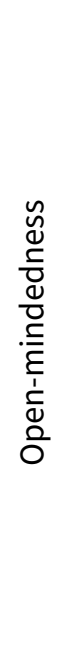 } & 0.54 & \multirow{10}{*}{0.73} & 28. & & 0.79 & \\
\hline 9. & & 0.32 & & 29. & & 0.63 & \\
\hline 10. & & 0.74 & & 30. & & 0.68 & \\
\hline 11. & & 0.64 & & 31. & & 0.75 & \\
\hline 12. & & 0.51 & & 32. & & 0.46 & \\
\hline 13. & & 0.44 & & 33. & \multirow{7}{*}{ 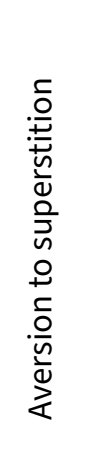 } & 0.52 & \multirow{8}{*}{0.68} \\
\hline 14. & & 0.75 & & 34. & & 0.64 & \\
\hline 15. & & 0.73 & & 35. & & 0.68 & \\
\hline 16. & & 0.51 & & 36. & & 0.47 & \\
\hline 17. & & 0.55 & & 37. & & 0.42 & \\
\hline 18. & & 0.64 & & 38. & & 0.59 & \\
\hline 19. & & 0.48 & & 39. & & 0.58 & \\
\hline 20. & & 0.67 & & & & & \\
\hline
\end{tabular}

\footnotetext{
*corr. is used as abbreviation for the word 'correlation'
} 
(Nunnaly, 1978; Cohen, 1988). It suggests that scale functions in a similar way for both male and female students. The scale is thus suitable for both the genders and the student scores over this scale will be highly reliable.

Since the content and construct validities of the scale had already been established by the expert opinions and in the previous tryouts. The predictive validity was further established in terms of student scores in physics, mathematics and English subjects in schools. The correlation coefficients between the student scores on scientific attitude scale and their respective scores in physics, mathematics and English subjects were calculated. The results show that student scores on scientific attitude scale have high correlation coefficients of 0.50 and 0.56 respectively with the student physics and mathematics scores. While the correlation coefficient between the student scientific attitude and the English scores is low i.e., 0.14. These correlation coefficients established the concurrent and discriminant validities of the scale as well (Hubley, 2014; Lin \& Yao, 2014). It represented that the draft-scale has strong quantitative reliability and validity. It is suitable for the assessment of scientific attitudes among the secondary school students under five sub-scales viz. rationality, open-mindedness, confidence in scientific method, curiosity, and aversion to superstitions.

\section{DISCUSSION}

The study results in to the development of a scientific attitude scale which is standardized through repeated tryouts over large student populations in India. The new scale was developed by making quantitative modifications in the original Bajwa \& Mahajan (2012) scientific attitude scale. Originally, the scale consisted of 49 items with five sub-scales described as below;

1. Rationality measures the ability of students to reason and apply logic to solve problems ( 9 items)

2. Curiosity defines the scientific behavior that includes the desire of understanding new situations, searching answers to why's and how's, and a desire to completeness of knowledge (6 items)

3. Open-Mindedness mainly deals with the ability to revise the existed opinions and conclusions. An ability to reject singular and original approaches with a desire to encounter new things and ideas (11 items)

4. Aversion to Superstitions includes the behavior that rejects superstitious beliefs and accepts only the scientific facts and explanations (10 items)

5. Faith in Scientific Method involves observable, empirical and measurable evidence for the reasoning principles. Thus, having a behavior to adopt scientific method to solve problems ( 13 items)
However, the modified scale in this study consists of 39 statements under five sub-scales namely rationality, open-mindedness, confidence in scientific method, curiosity, and aversion to superstitions with 7,10,9,6 and 7 number of statements respectively. This new modified scale overcomes the shortcomings of the Bajwa \& Mahajan (2012) scale and can also be proved to be efficient over all the other scientific attitude scales available in India since it is repeatedly and rigorously standardized through experts and student tryouts. The statements in Bajwa \& Mahajan (2012) scale were less precise, irrelevant and poorly framed in context to the scale. The new scale holds strong theoretical foundations while all the statements have been proved to be unambiguous.

The Bajwa \& Mahajan (2012) scale was standardized over a smaller group, the newly developed scale is tested with repeated tryouts over 200, 312, and 641 students. This new scale has high item to scale correlations for all the statements. The Bajwa \& Mahajan (2012) scale has poor statistical results, but the EFA, reliability and validity analyses in the new scale further confirm its strong hold as an efficient scale for the measurement of scientific attitudes among the students. The new scale is also fivepoint Likert scale, it requires the students to mark their responses on a range of 'strongly agree' to 'strongly disagree'. The scale is clear in its notion for the assessment of scientific attitudes among the students, the language of all statements is established as unambiguous, the presence of five sub-scales is justified through EFA, the statements and sub-scales have higher correlation values with the scale. Thus, the developed scale has strong psychometric properties as established statistically. The current study thus results in to the development of a reliable and valid scientific attitude scale.

\section{SUMMARY AND CONCLUSION}

In India, several researchers have been conducted in relation to scientific attitudes in connection with various factors of student academic success. Scientific attitudes are quite popular among the researchers and these researches involved several national level scales for the measurement of scientific attitudes in India, since a number of locally standardized scientific attitude scales are available. The current study has reviewed 23 such available scales, based on five parameters of a scale's psychometric evidences. The review showed that most of the available scales lack theoretical foundations and they are poorly standardized over small samples. A scale by Bajwa \& Mahajan (2012) was selected based on its theoretical foundations, it described five sub-scales of scientific attitudes (rationality, curiosity, open-mindedness, aversion to superstition, and faith in scientific method) as aligned 
with the description of scientific attitudes by Gauld \& Hukins (1980). Since the scale has weak standardization over just 52 students, it was subjected to a validity checkup. The scale failed the validity test with 12 experts and 218 student try-out. Thus, the need of a new scale was felt.

To develop a new scale, the sub-scales and some of the items of the Bajwa \& Mahajan (2012) scale were retained. The remaining items were deleted, and some new items were added. A 49-items scale was given for 11 science education experts' opinions. After calculating the CVR values 5 items were dropped. The 44-statements scale was then subjected to an initial tryout over 200 students. The correlation coefficients of 5 more statements were low, so they were deleted as well. The scale now had 39 statements, which were further subjected for language test over 28 students. Now all the 39 -items had content validity, good correlation values and language. A second try-out was carried out over 312 students and EFA was utilized. EFA resulted in significant KMO measure and Bartlett's test of sphericity. Each of the scale-item had high communalities and factor loadings. The scree plot further established the existence of five sub-scales in the scale. The total variance explained was also high i.e., $59.7 \%$. Yet, the reliability and validity analyses of the scale were performed over a larger sample of 641 students. The results show a Cronbach's alpha coefficient value of 0.79 which is quite high. The separate Cronbach's alpha coefficients for the male and female students were 0.73 and 0.83 respectively. It indicated that the scale work similarly for both the genders. The content, construct, concurrent and discriminatory validities of the scale were also established.

The current study thus yields a valid assessment tool for the evaluation of scientific attitudes among the students. The analyses results show that the developed scale is an effective instrument with strong psychometric evidences for the measurement of scientific attitudes with five sub-sales namely rationality, open-mindedness, confidence in scientific method, curiosity, and aversion to superstitions. The developed scale can be proved to be an important assessment instrument for the scientific attitudes, it is newly developed, validated/standardized statistically, and can be utilized worldwide. The scale can be exploited by the teachers for the internal assessments during coursework, to yield precise results regarding the attainment of scientific attitudes among the students. Correspondingly, suitable teaching strategies and classroom practices could be executed for the development of significant changes among the students' scientific attitudes. The scale can be used in future researches where researchers wish to study scientific attitudes of the students. Thus, the present scale will serve as a useful instrument for the researchers and teachers towards the assessment of scientific attitudes.

\section{DECLARATION OF CONFLICTING INTERESTS}

The authors declared no potential conflicts of interest with respect to the research, authorship, and/or publication of this article.

\section{ACKNOWLEDGEMENTS}

The author acknowledges the comments/suggestions from an unknown reviewer, they helped a lot in making the manuscript suitable for the publication.

\section{REFERENCES}

Ahmed, T. S. M. (2007). Effect of scientific aptitude and scientific attitude on academic achievement of secondary school students in Science (Karnatak University). Retrieved from https://shodhganga.inflibnet.ac.in/handle/10603/95379

Ahuja, A. (2017). Study of scientific attitude in relation to science achievement scores among secondary school students. Educational Quest: An International Journal of Education and Applied Social Science, 8(1), 9-16. https://doi. org/10.5958/2230-7311.2017.00002.2

Aiken, L. R., \& Aiken, D. R. (1969). Recent research on attitudes concerning science. Science Education, 53(4), 295-305. https://doi.org/10.1002/sce.3730530405

Bajwa, S. \& Mahajan, M. (2012). Scientific attitude scale. Agra: National Psychology Corporation.

Balaji, G. (2017). Role of science teacher in developing scientific attitude among secondary school students. Scholarly Research Journal for Interdisciplinary Studies, 4(37). https:// doi.org/10.21922/srjis.v4i37.10552

Barot, Y. K. (2013). A Study of scientific attitudes of students of secondary level in context of certain variables. International Journal for Research in Education, 2(1). Retrieved from www. raijmr.com

Baumel, H. B., \& Berger, J. J. (1965). An attempt to measure scientific attitudes. Science Education, 49(3), 267-269. https:// doi.org/10.1002/sce.3730490318

Baweja, M. (2017). A study of errors and misconception in science in relation to scientific attitude among secondary school students. International Journal of Advance Research, 5(3), 1707-1710. https://doi.org/10.21474/IJAR01/3682

Bhagwat, S. (2006). Scientific attitude scale. Agra: National Psychology Corporation.

Bhattacharjee, J. (2015). Construction of science attitude scale. International Research Journal of Interdisciplinary \& Multidisciplinary Studies, 1(3), 35-42.

Billeh, V. Y., \& Zakhariades, G. A. (1975). The development and application of a scale for measuring scientific attitudes. Science Education, 59(2), 155-165. https://doi.org/10.1002/ sce.3730590203

Blalock, C. L., Lichtenstein, M. J., Owen, S., Pruski, L., Marshall, C., \& Toepperwein, M. (2008). In pursuit of validity: A comprehensive review of science attitude instruments 19352005. International Journal of Science Education, 30(7), 961977. https://doi.org/10.1080/09500690701344578

Candrasekaran, S. (2014). Developing scientific attitude, crit- 
ical thinking and creative intelligence of higher secondary school biology students by applying synectics techniques. International Journal of Humanities and Social Science Invention, 3(6), 1-8. Retrieved from www.ijhssi.org

Cattell, R. B. (1966). The scree test for the number of factors. Multivariate Behavioral Research, 1(2), 245-276. https://doi. org/10.1207/s15327906mbr0102_10

CBSE. (2016). Central Board of secondary education seneral studies (Syllabus and Guidelines) classes XI and XII. Retrieved from http://cbseacademic.nic.in/web_material/ CurriculumMain20/SrSecondary/General_Studies.pdf

CBSE. (2019). CBSE | Academics Unit: Curriculum/Syllabus. Retrieved 9 March 2020, from Curriculum for the Academic Year 2019-20 website: http://cbseacademic.nic.in/curriculum.html

Cohen, J. (1988). Statistical power analysis for the behavioral sciences (2nd ed.). NJ: Erlbaum Hillsdale.

Costello, A. B., \& Osborne, J. W. (2005). Best practices in exploratory factor analysis: Four recommendations for getting the most from your analysis. Practical Assessment, Research \& Evaluation, 10(7), 1-9. Retrieved from http://www.statsoft. com/textbook/

Dani, D. N. (1989). Scientific attitude and cognitive styles. Retrieved from Google books.

Drake, W. E. (1935). The need for a scientific attitude. The High School Journal, 18(7), 229-232. https://doi. org/10.2307/40366754

Ekawati, E. Y. (2017). A model of scientific attitudes assessment by observation in physics learning based scientific approach: case study of dynamic fluid topic in high school. Journal of Physics: Conference Series, 795, 012056. https:// doi.org/10.1088/1742-6596/795/1/012056

Field, A. (2009). Discovering statistics using SPSS. London: Sage.

Fraser, B. J. (1978). Use of content analysis in examining changes in science education aims over time. Science Education, 62(1), 135-141. https://doi.org/10.1002/sce.3730620118

Gakhar, S. C. \& Kaur, A. (1985). Scientific attitude scale. Agra: National Psychology Corporation.

Gardner, P. L. (1975). Attitudes to science: A review. studies in science education, 2(1), 1-41. https://doi. org/10.1080/03057267508559818

Gauld, C. F., \& Hukins, A. A. (1980). Scientific attitudes: A review. Studies in Science Education, 7(1), 129-161. https://doi. org/10.1080/03057268008559877

George, D., \& Mallery, P. (2003). SPSS for windows step by step: A simple guide and reference. Boston: Allyn \& Bacon.

Ghosh, S. (1986). A critical study of scientific attitude and aptitude of the students and determination of some determinants of scientific aptitude (University of Kalyani). Retrieved from https://shodhganga.inflibnet.ac.in/handle/10603/241013

Government of India. (1986). National Policy on Education 1986. Retrieved from https://mhrd.gov.in/sites/upload files/ mhrd/files/upload document/NPE86-mod92.pdf

Grewal, A. (1990). Science attitude scale. Agra: National Psychology Corporation.

Gupta, S. (2015). Influence of students' gender and stream of study on scientific attitude and attitudes towards science. International Journal of Research - GRANTHAALAYAH, 3(12), 187-194.

Haney, R. E. (1964). The development of scientific attitudes. The Science Teacher, 31(8), 33-35.

Heiss, E. D. (1958). Helping Students develop a Scientific Attitude. The Science Teacher, 25(7), 371-373.
Hubley, A. M. (2014). Discriminant Validity. In Alex C. Michalos (Ed.), Encyclopedia of Quality of Life and Well-Being Research (pp. 69-311). https://doi.org/10.1007/978-94-007-07535_751

Hunashal, S. S. (2013). A Study of Scientific Creativity Scientific Attitude and Scientific Interest in Relation to the Academic Achievement of Ninth Standard Students of Bijapur (Karnataka State Womens University). Retrieved from https://shodhganga.inflibnet.ac.in/handle/10603/160471

Jain, S.N. (1967). An Investigation into The Construction of Scientific Attitude Scale for India Youth, New Delhi: Project Report NCERT

Jones, B., \& Butts, B. (1983). Development of a set of scales to measure selected scientific attitudes. Research in Science Education, 13(1), 133-140. https://doi.org/10.1007/ BF02356700

Kaur, M., Niwas, R., \& Rai, V. K. (2015). Achievement in science in relation to Sex, Habitation and Scientific Attitude of Higher Secondary School Students. International Journal of Scientific Research Education, 4(7), 7-10.

Kavitha, S., \& Venkateswaran, R. (2014). Relationship between scientific attitude and teaching competency of prospective B.Ed teachers. Shanlax International Journal of Education, 3(1), 60-65.

Khan, M., \& Siddiqui, M. A. (2018). A study of scientific attitude, teaching effectiveness and physics achievement among physicssenior secondary students. IMPACT: International Journal of Research in Humanities, Arts and Literature, 6(8), 71-78. Retrieved from www.impactjournals.us

Khan, P. (1962). An experimental study to determine the effect of a selected procedure for teaching the scientific attitudes to seventh and eighth grade boys through the use of current events in science. Science Education, 46(2), 115-127. https:// doi.org/10.1002/sce.3730460209

Koballa, T. R., \& Glynn, S. M. (2013). Handbook of reseach on science education (S. K. Abell, K. Appleton, \& D. L. Hanuscin, Eds.). https://doi.org/10.4324/9780203824696-8

Kozlow, M. J., \& Nay, M. A. (1976). An approach to measuring scientific attitudes. Science Education, 60(2), 147-172. https:// doi.org/10.1002/sce.3730600203

Lawshe, C. H. (1975). A quantitative approach to content validity. Personnel Psychology, 28(4), 563-575. https://doi. org/10.1111/j.1744-6570.1975.tb01393.x

Lawson, D. E. (1959). Truth, values, and the scientific attitude. The Educational Forum, 24(1), 85-93. https://doi. org/10.1080/00131725909339483

Lin, W.-L., \& Yao, G. (2014). Concurrent validity. In Encyclopedia of Quality of Life and Well-Being Research (pp. 1184-1185). https://doi.org/10.1007/978-94-007-0753-5_516

Lucas, P. (2016). A study of scientific attitude and academic achievement in science of secondary school students in Thane city. Anveshana's International Journal of Research in Education, Literature, Psychology and Library Sciences, 1(1), 68-74.

Mahulae, P. S., Sirait, M., \& Sirait, M. (2017). The effect of inquiry training learning model using PhET media and scientific attitude on students' science process skills. IOSR Journal of Research \& Method in Education, 7(5), 24-29. https://doi. org/10.9790/7388-0705012429

Misra, K.S. 2008. Construction and standardization of scientific attitude questionnaire. Journal of Educational Studies, 4(1), 1-5.

Moore, R. W., \& Foy, R. L. H. (1997). The scientific attitude inven- 
tory: A revision (SAI II). Journal of Research in Science Teaching, 34(4), 327-336. https://doi.org/10.1002/(SICI)10982736(199704)34:4<327::AID-TEA3>3.0.CO;2-T

National Council of Educational Research and Training, (2006). Position paper of national focus group on teaching of science, NCERT, New Delhi: India. Retrieved from http://www. ncert.nic.in/new_ncert/ncert/ rightside/links/ pdf/ focus_ group/science.pdf

National Council of Educational Research and Training. (2019). National Library of Education \& Psychological Test (NLEPT) Catalogue of Tests. In Department of Educational Psychology and Foundations of Education, NCERT. Retrieved from http://www.ncert.nic.in/announcements/oth_announcements/pdf_files/NLEPT_Catalogue.pdf

National Curriculum Framework (2005). National Council of Educational Research and Training (NCERT). New Delhi.

National Psychological Corporation. (2019). Catalogue 2019. Retrieved from http://www.npcindia.com/downloads/Catalogue-NPC-2019.pdf

Noll, V. H. (1935). Measuring the scientific attitude. The Journal of Abnormal and Social Psychology, 30(2), 145-154. https:// doi.org/10.1037/h0059829

Nunnaly, J. (1978). Psychometric theory. New York: McGraw-Hill.

Osborne, J., Simon, S., \& Collins, S. (2003). Attitudes towards science: A review of the literature and its implications. International Journal of Science Education, 25(9), 1049-1079. https://doi.org/10.1080/0950069032000032199

Ramachandra, S. (2017). A Case Study of Role of Scientific Attitude and Family Education of Mentally Retarded Dropouts Doctor of Philosophy in Education (Gulbarga University). Retrieved from http://shodhganga.inflibnet.ac.in:8080/jspui/ handle/10603/204666

Ramya, K. S. (2018). A Study on Environmental Ethics Scientific Attitude And Attitude Towards Sustainable Development Among Secondary School Teachers (Mangalore University). Retrieved from https://shodhganga.inflibnet.ac.in/handle/10603/249855

Ranganath, A. (2012). A study of creativity scientific attitude and attitude towards science of prospective science teachers of Andhra Pradesh (Acharya Nagarjuna University). Retrieved from https://shodhganga.inflibnet.ac.in/handle/10603/127013

Rao, D. B. (2003). Scientific attitude vis-a-vis scientific aptitude (M. Ediger, Ed.). New Delhi: Discovery Publishing House Pvt. Ltd.

Rao, D. B. (2004). Scientific attitude, scientific aptitude and achievement (1st ed.). Retrieved from Google books.

Rasani, S. (2017). Scientific Literacy and Scientific Attitude among Students at the Higher Secondary Level (Mother Teresa Women's University). Retrieved from https://shodhganga.inflibnet.ac.in/handle/10603/178024

Rashmi, J., \& Betsur, N. C. (2017). A study on the relationship between scientific attitude and academic achievement among senior secondary level science students. Indian Streams Research Journal, 6(12), 1-5.

Ravi, S. (2013). An investigation into scientific attitude and achievement in science of 9th class students in relation to certain psycho sociological factors (Sri Venkateswara University). Retrieved from https://shodhganga.inflibnet.ac.in/ handle/10603/143924

Sagar, J. V. (2003). Scientific attitude and higher education. New Delhi: Anmol Publications Pvt. Ltd.

Schibeci, R. A. (1981). Do teachers rate science attitude objec- tives as highly as cognitive objectives? Journal of Research in Science Teaching, 18(1), 69-72. https://doi.org/10.1002/ tea.3660180111

Schibeci, R. A. (1984). Attitudes to science: an update. Studies in Science Education, 11(1), 26-59. https://doi. org/10.1080/03057268408559913

Shanthi, G. (2014). Scientific attitude and academic achievement of secondary school students in coimbatore district. Shanlax International Journal of Education, 2(2), 1.

Singh, M. (1993). A study of the effect of problem solving teaching strategy on scientific attitude and scientific creative thinking of secondary school students of Jhansi division U P (Himachal Pradesh University). Retrieved from http://shodhganga.inflibnet.ac.in:8080/jspui/handle/10603/128153

Singh, Y. C., \& Bai, A. C. (2017). A study of scientific attitude and science interest of secondary school students in West Tripura District. Paripex- Indian Journal of Research, 6(6), 171-173.

Smitha, V. P. (2012). Inquiry training model and guided discovery learning for fostering critical thinking and scientific attitude (first edit). Retrieved from Google books.

Sood, J. K. \& Sandhya, R. P. (1978). In Hunshal, S. (2013). A Study of Scientific Creativity Scientific Attitude and Scientific Interest in Relation to the Academic Achievement of Ninth Standard Students of Bijapur (Karnataka State Women's University). Retrieved from https://shodhganga.inflibnet. ac.in/handle/10603/160471.

Srivastava, N. N. (1980). A study of scientific attitude and its measurement. Unpublished Ph.D. Thesis, Patna University, Patna.

Srivastava, S. (2013). A study of relationship between environmental moral reasoning and scientific attitude among secondary students. Online International Interdisciplinary Research Journal, 3(4), 134-139.

Srivastava, S. (2014). Achievement in science as predictors of students' scientific attitude. European Academic Research, 2(2), 2879-2893.

Sudipta, C. (2015). A Study on Scientific Attitude of Secondary School Students of Dibrugarh District of Assam (Dibrugarh University). Retrieved from https://shodhganga.inflibnet. ac.in/handle/10603/250121

Sumita, S. S. (2017). A Study of scientific attitude development of junior college student through various activities in the junior college (Shri Jagdishprasad Jhabarmal Tibarewala University). Retrieved from https://shodhganga.inflibnet.ac.in/ handle/10603/192856

Supardi, R., Istiyono, E., \& Setialaksana, W. (2019). Developing scientific attitudes instrument of students in chemistry. Journal of Physics: Conference Series Paper, 01233, 12025. https://doi.org/10.1088/1742-6596/1233/1/012025

Trivedi, P., \& Agarwal, S. (2016). To study the scientific attitude and self-efficacy of secondary school students of Chandrapur district. Pune Research Scholar: An International Multidisciplinary Journal, 2(5), 1-6.

Velicer, W. F., \& Fava, J. L. (1998). Effects of variable and subject sampling on factor pattern recovery. Psychological Methods, 3(2), 231-251. 